\title{
Hubungan Rasio CT dan Ekspresi Gen $E$ dengan Kejadian Gagal Napas pada Pasien Covid-19 Rawat Inap di RS X
}

\author{
Dika Rifky Fernanda*, Lelly Yuniarti \\ Prodi Pendidikan Kedokteran, Fakultas Kedokteran, Universitas Islam \\ Bandung, Indonesia. \\ *dikaarifky@gmail.com, lelly.yuniarti@gmail.com
}

\begin{abstract}
Introduction: Corona virus disease 2019 (COVID-19) is a new disease that causes millions of deaths worldwide. The majority of deaths are due to pulmonary degeneration leading to respiratory failure. The gold standard for COVID-19 diagnostics is the examination of the nucleic acid of the SARS-CoV-2 virus using RT-PCR which produces CT values for the SARS-CoV-2 gene target and internal control (CT). One of the target genes that is often examined in COVID-19 examination is gene E. This study aims to analyze the relationship between the CT IC/CT gene E ratio and the relative expression of the SARS-CoV-2 E gene with the incidence of respiratory failure. Methods: This study is a cross sectional study conducted at X General Hospital on 196 patients. Data obtained from medical records in the form of patient characteristics and PCR examination results from the laboratory. Relative gene expression was calculated using the livak method (2$\Delta \Delta \mathrm{CT})$. The $\mathrm{CT}$ ratio was calculated by comparing the internal control CT with the CT gene E. The relationship of gene relative expression and CT ratio with the incidence of respiratory failure was analyzed using thestatistic unpaired t-test at $95 \%$ confidence level. Results: The results showed that the characteristics of COVID-19 patients were more males, aged 41-60 and 40 of the total patients experienced pulmonary distress. The unpaired t-test showed that there was no relationship between the CT IC/CT gene E ratio and the relative expression of the SARS-CoV-2 gene $\mathrm{E}$ and the incidence of respiratory failure, with $\mathrm{P}$ values $(\mathrm{P}=0.2083)$ and $(\mathrm{P}=0,8018)$. Conclusion: The conclusion of this study is that there is no relationship between the ratio of internal control CT/CT of the SARS-CoV-2 gene and the relative expression level of the SARS-CoV-2 E gene with the incidence of respiratory failure in confirmed COVID-19 patients hospitalized at Hospital X. There are several factors that influence the incidence of respiratory failure in addition to comorbidities such as age and gender.
\end{abstract}

Keywords: COVID-19, Ct value, gene relative expression, respiratory failure, gene $E$.

\begin{abstract}
Abstrak. Pendahuluan: Corona virus disease 2019 (COVID-19) adalah penyakit baru yang menyebabkan jutaan kematian di seluruh dunia. Mayoritas kematian disebabkan oleh perburukan paru yang berujung pada gagal napas. Standar baku emas diagnostik COVID-19 adalah pemeriksaan asam nukleat virus SARS-CoV-2 dengan menggunakan RT-PCR yang menghasilkan nilai CT target gen SARS-CoV-2 dan internal control (CT). Salah satu gen target yang sering diperiksa pada pemeriksaan COVID-19 adalah gen E. Penelitian ini bertujuan untuk menganalisis hubungan rasio CT IC/CT gen E dan ekspresi relatif gen E SARS-CoV-2 dengan kejadian gagal napas. Metode: Penelitian ini merupakan penelitian cross sectional yang dilakukan di RS X pada 196 pasien. Data diperoleh dari medical record berupa karakteristik pasien dan hasil pemeriksaan PCR dari laboratorium. Ekspresi gen relatif dihitung dengan menggunakan metode livak (2- $\Delta \Delta \mathrm{CT})$. Rasio $\mathrm{CT}$ dihitung dengan membandingkan $\mathrm{CT}$ internal control dengan $\mathrm{CT}$ gen E. Hubungan ekspresi relatif gen dan rasio CT dengan kejadian gagal napas dianalisis menggunakan uji statistik unpaired t-test pada tingkat kepercayaan 95\%. Hasil: Hasil penelitian didapatkan karakteristik pasien COVID-19 lebih banyak laki-laki, usia 41-60 dan 40 orang dari total pasien mengalami pulmonary distress. Uji unpaired t-test menujukan tidak terdapat hubungan antara rasio CT IC/CT gen E dan ekspresi relatif gen E SARS-CoV-2 dengan kejadian gagal napas, dengan nilai $\mathrm{P}$ berturut-turut $\mathrm{P}=0,2083$ dan $\mathrm{P}=0,8018$. Kesimpulan: Kesimpulan penelitian ini adalah tidak terdapat hubungan antara rasio $\mathrm{CT}$ internal control/CT gen E SARS-CoV-2 dan tingkat ekspresi relatif gen E SARS-
\end{abstract}


108 | Dika Rifky Fernanda, et al.

CoV-2 dengan kejadian gagal napas pada pasien terkonfirmasi COVID-19 yang dirawat inap di RS X. Terdapat beberapa faktor yang memengaruhi kejadian gagal napas selain komorbid seperti usia dan jenis kelamin.

Kata Kunci: COVID-19, Ct value, ekspresi relatif gen, gagal napas, gen E. 


\section{A. Pendahuluan}

Corona virus disease 19 (COVID-19) merupakan penyakit baru yang disebabkan oleh severe acute respiratory syndrome coronavirus 2 (SARS-CoV-2), virus ini menyebabkan pandemi di dunia pada akhir tahun 2020 dengan ratusan juta kasus dan jutaan kematian. Kejadian dan kematian yang tinggi disebabkan oleh mudah terjadinya penyebaran virus serta perburukan manifestasi akibat dari kerusakan alveolus secara masif dan multiple organ failures sehingga menyebabkan outcome fatal yang dikenal dengan kondisi gagal napas dan berujung pada kematian pasien. ${ }^{1}$

Diagnosa awal merupakan kunci utama pencegahan terjadinya perburukan manifestasi pasien. Standar baku emas pemeriksaan COVID-19 sekarang adalah dengan menggunakan real time polymerase chain reaction (RT-PCR) yang mengonfirmasi diagnosis dengan memperbanyak asam nukleat virus sampai virus terdeteksi. ${ }^{2}$ Pemeriksaan ini akan menghasilkan cycle treshold (CT) value yang didefinisikan sebagai jumlah siklus amplifikasi yang dibutuhkan untuk mencapai treshold sehingga asam nukleat virus terdeteksi. ${ }^{2}$ Hasil CT berbanding terbalik dengan jumlah asam nukleat virus yang terdapat dalam sampel. Nilai CT yang rendah menunjukkan siklus amplifikasi yang dibutuhkan untuk mencapai threshold lebih sedikit karena asam nukleat yang terkandung tinggi dalam sample. ${ }^{3}$ Pada pemeriksaan RT-PCR akan dihasilkan CT internal control sebagai standar yang merupakan house keeping gene. Target gen utama pemeriksaan ini adalah gen $E$ (envelope) sebagai first line screening yang direkomendasikan World Health Organization (WHO) yang juga digunakan sebagai target gen pemeriksaan COVID-19 di mayoritas laboratorium di Indonesia. ${ }^{4-6}$

Sampai saat ini pemeriksaan RT-PCR digunakan oleh tenaga kesehatan hanya untuk melihat ada tidaknya virus pada pasien, ${ }^{7}$ padahal prinsip dan proses PCR dapat digunakan untuk menghitung tingkat ekspresi gen SARS-CoV-2 yang dapat menunjukkan viral load. Viral load yang tinggi dapat menyebabkan manifestasi klinis yang buruk pada pasien COVID-19. Hasil PCR berupa data CT dapat digunakan untuk menganalisis tingkat ekspresi gen dan memprediksi manifestasi klinis, sehingga dapat menjadi prediktor perburukan penyakit pada pasien COVID19. ${ }^{2,8-10}$ Tujuan penelitian ini adalah menganalisis hubungan rasio CT IC/CT gen $E$ dan ekspresi relatif gen E SARS-CoV-2 dengan kejadian gagal napas.

\section{B. Metodologi Penelitian}

Penelitian ini menggunakan desain penelitian observasional analitik dengan metode cross sectional yang dilakukan di RS X. Pengambilan sampel dilakukan dengan teknik purposive sampling dari medical record pasien terkonfirmasi positif COVID-19 yang dirawat inap di RS X pada periode Oktober-Desember 2020. Kriteria inklusi meliputi pasien yang terkonfirmasi COVID-19 dan usia lebih atau sama dengan 17 tahun, dengan kriteria eksklusi meliputi pasien yang memiliki riwayat komorbid dan medical record yang tidak lengkap. Analisis hubungan rasio CT IC/CT gen $E$ dan ekspresi relatif gen $E$ $S A R S$-CoV-2 dengan kejadian gagal napas diuji menggunakan uji statistik unpaired $t$ test pada tingkat kepercayaan 95\% (nilai $\mathrm{p}<0,05$ dianggap signifikan). Data ditabulasi dan kemudian diolah menggunakan software Statistik Graph pad Prism Versi 9.2.0 (322).

\section{Hasil Penelitian dan Pembahasan}

\section{Karakteristik Populasi}

Jumlah subjek penelitian COVID-19 di Rumah Sakit X sebanyak 196. Subjek yang sesuai dengan kriteria inklusi dan tidak sesuai dengan kriteria eksklusi untuk mencari hubungan antara gen E dan gagal napas sebanyak 87 pasien. Karakteristik pasien berdasar atas usia terdiri dari usia $17 \square 40$ sebanyak 38 pasien $(19,4 \%)$, usia $41 \square 60$ tahun sebanyak 98 pasien (50\%), dan di atas 61 tahun sebanyak 60 pasien (30,6\%). Jumlah pasien laki-laki sebanyak 99 pasien (50,5\%). Berdasar atas tanda dan gejala, demam 146 pasien $(74,5 \%)$, sesak 133 pasien $(67,9 \%)$, ISPA 63 pasien $(32,1 \%)$, pusing 56 pasien $(28,6 \%)$, pneumonia 51 pasien $(26,0 \%)$, pulmonary distress 40 pasien $(20,4 \%)$, nyeri dada 36 pasien $(18,4 \%)$, renal injury 32 pasien $(16,3 \%)$, diare 29 pasien

JRK is licensed under Creative Commons Attribution-

NonCommercial-ShareAlike 4.0 International License. Kedokteran 
$(14,8 \%)$, cardiac injury 20 pasien $(10,2 \%)$, anosmia 9 pasien $(4,6 \%)$, gangguan BAB 6 pasien $(3,1 \%)$. Berdasar atas hasil ronsen pasien yang mengalami bronhopneumonia bilateral sebanyak 143 pasien $(73,0 \%)$, normal 33 pasien $(16,8 \%)$, pneumonia 9 pasien $(4,6 \%)$, TB paru 1 pasien $(0,5 \%)$. Pasien dengan penyakit penyerta sebanyak $113(57,6 \%)$, pasien hipertensi 68 orang $(60,2 \%)$, gagal ginjal 44 pasien $(38,9 \%)$, diabetes melitus 34 pasien $(30,1 \%)$, dan pasien dengan komorbid lebih dari 1 sebanyak 36 pasien $(18,4 \%)$. Berdasar atas lama rawat dan kematian pasien meninggal dengan durasi lama rawat $1 \square 7$ hari 25 pasien (74,7\%), $8 \square 14$ hari 8 pasien $(24,2 \%)$, pasien hidup dengan durasi lama rawat $1 \square 7$ hari 92 pasien $(56,4 \%), 8 \square 14$ hari 62 pasien (38,0\%), lebih dari sama dengan 15 hari 9 pasien (5,5\%) (Tabel 1).

Tabel 1. Karakteristik Klinis dan Komorbiditas Pasien COVID-19 yang dirawat inap di RS X

\begin{tabular}{|c|c|c|}
\hline Jenis Kelamin & Jumlah(n=196) & Persentase $(\%)$ \\
\hline Wanita & 97 & $49,5 \%$ \\
\hline Pria & 99 & $50,5 \%$ \\
\hline \multicolumn{3}{|l|}{ Usia } \\
\hline $17-40$ & 38 & $19,4 \%$ \\
\hline $41-60$ & 98 & $50,0 \%$ \\
\hline$>61$ & 60 & $30,6 \%$ \\
\hline Manifestasi Klinis & $\operatorname{Jumlah}(n=196)$ & Persentase $(\%)$ \\
\hline ISPA & 63 & $32,1 \%$ \\
\hline Sesak & 133 & $67,9 \%$ \\
\hline Anosmia & 9 & $4,6 \%$ \\
\hline Nyeri Dada & 36 & $18,4 \%$ \\
\hline Gangguan $\mathrm{BAB}$ & 6 & $3,1 \%$ \\
\hline Demam & 146 & $74,5 \%$ \\
\hline Pusing & 56 & $28,6 \%$ \\
\hline Diare & 29 & $14,8 \%$ \\
\hline Cardiac Injury & 20 & $10,2 \%$ \\
\hline Renal Injury & 32 & $16,3 \%$ \\
\hline Pulmonary Distress & 40 & $20,4 \%$ \\
\hline Pneumonia & 51 & $26,0 \%$ \\
\hline $\begin{array}{l}\text { Hasil Ronsen } \\
\text { Toraks }\end{array}$ & Jumlah (n=196) & Persentase (\%) \\
\hline $\begin{array}{l}\text { Bronchopneumonia } \\
\text { Bilateral }\end{array}$ & 143 & $73,0 \%$ \\
\hline Normal & 33 & $16,8 \%$ \\
\hline Pneumonia & 9 & $4,6 \%$ \\
\hline TB Paru & 1 & $0,5 \%$ \\
\hline Faktor Risiko & Jumlah(n=196) & Persentase (\%) \\
\hline Tidak ada komorbid & 83 & $42,3 \%$ \\
\hline Komorbid & 113 & $57,6 \%$ \\
\hline Hipertensi & 68 & $60,2 \%$ \\
\hline Diabetes melitus & 34 & $30,1 \%$ \\
\hline Renal Failure & 44 & $38,9 \%$ \\
\hline $\begin{array}{l}\text { Pasien dengan Komorbid lebih } \\
>1\end{array}$ & 36 & $18,4 \%$ \\
\hline
\end{tabular}




\begin{tabular}{|lcccc|}
\hline $\begin{array}{l}\text { Lama } \\
\text { Perawatan } \\
\text { (Hari) }\end{array}$ & $(\mathbf{n = 3 3 )}$ & $\begin{array}{c}\text { Meninggal Persentase } \\
(\boldsymbol{\%})\end{array}$ & $\mathbf{( n = 1 6 3 )}$ & $\begin{array}{c}\text { Hidup } \\
\text { Persentase } \\
(\%)\end{array}$ \\
\hline $1-7$ & 25 & $74,76 \%$ & 92 & $56,4 \%$ \\
$8-14$ & 8 & $24,24 \%$ & 62 & $38,0 \%$ \\
$\geq 15$ & 0 & $0 \%$ & 9 & $5,5 \%$ \\
\hline
\end{tabular}

Hubungan rasio CT IC/CT gen E SARS-CoV-2 dengan Gagal napas

Hasil uji beda dengan menggunakan uji statistik unpaired $t$-test menunjukkan tidak ada hubungan antara rasio CT IC/CT gen E SARS-CoV-2 dan kejadian gagal napas pada pasien COVID-19 yang dirawat inap di RS X (Gambar 1).

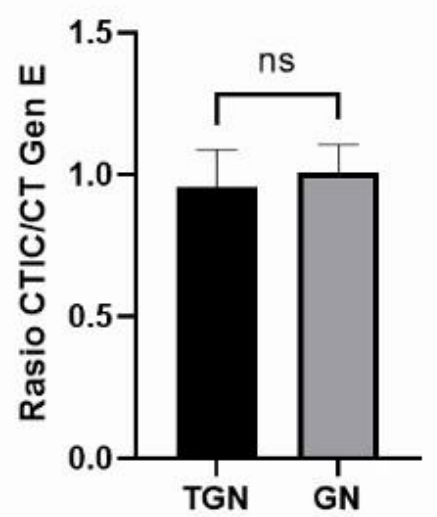

Gambar 1. Diagram Rasio CT IC/CT Gen E SARS-CoV-2 dengan Kejadian Gagal Napas

TGN: tidak gagal napas; GN: gagal napas

\section{Hubungan Ekspresi Relatif Gen E SARS-CoV-2 dengan Gagal Napas}

Hasil uji beda dengan menggunakan uji statistik unpaired t-test menunjukkan tidak adanya hubungan antara ekspresi relatif gen E SARS-CoV-2 dan kejadian gagal napas pada pasien COVID-19 yang dirawat inap di RS X (Gambar 2).

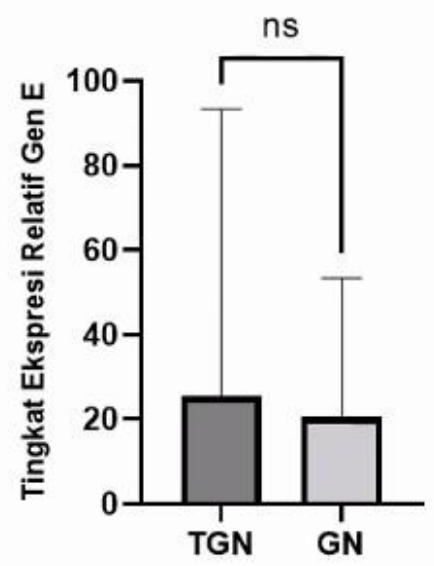

Gambar 2. Diagram Ekspresi Relatif Gen E SARS-CoV-2 dengan Kejadian Gagal Napas

TGN: tidak gagal napas; GN: gagal napas

JRK is licensed under Creative Commons Attribution-

NonCommercial-ShareAlike 4.0 International License. Kedokteran 
Hasil uji beda unpaired t-test menunjukkan tidak adanya hubungan antara rasio CT IC/CT gen E dan ekspresi relatif gen E SARS-CoV-2 dengan kejadian gagal napas pada pasien COVID-19 (dengan p>0,05). Tabel hubungan rasio CT IC/CT gen E dan ekspresi relatif gen $\mathrm{E}$ SARS-CoV-2 dengan kejadian gagal napas dapat dilihat pada Tabel 2 dan Tabel 3.

Tabel 2. Tabel Hubungan Rasio CT IC/CT Gen E SARS-CoV-2 dengan Kejadian Gagal Napas

Gen $S A R S-C o V-2$

Rasio

Nilai

\begin{tabular}{lccc}
\hline Gen $E$ & & \\
Mean \pm Std & $1 \pm 0,09$ & $0,95 \pm 0,13$ & \\
Median & 1 & 0,9 & 0,2083 \\
Range (min- & $0,34(0,84-$ & $0,49(0,77-1,26)$ & \\
maks) & $1,18)$ & \\
\hline \multicolumn{4}{c}{ Analisis menggunakan uji unpaired t-test pada tingat kepercayaan $95 \%}$.
\end{tabular}

Tabel 3. Tabel Hubungan Ekspresi Relatif Gen E SARS-CoV-2 dengan Kejadian Gagal Napas

Gen $S A R S-C o V-2$

Ekspresi

Nilai

p

Gagal napas Tidak Gagal Napas

$\begin{array}{lccc}\text { Gen } E & & & \\ \text { Mean } \pm \text { Std } & 20,52 \pm 32,83 & 25,43 \pm 67,83 & \\ \text { Median } & 5,280 & 0,64 & 0,8018 \\ \text { Range (min-maks) } & 115,3 & 326,3(0,01-326,3) & \\ & (0,11-115,4) & & \end{array}$

Analisis menggunakan uji unpaired t-test pada tingat kepercayaan $95 \%$.

\section{Diskusi}

Kasus pertama COVID-19 di Indonesia ditemukan pada bulan Maret 2020 dan insidensinya terus meningkat sampai sekarang. ${ }^{10}$ Dalam penelitian ini, data pasien COVID-19 diambil dari Rumah Sakit $\mathrm{X}$ berdasar atas jenis kelamin, usia, manifestasi, rontgen, komorbid, lama perawatan dan kematian. Hal ini sangat penting untuk memahami faktor risiko suatu penyakit yang dapat memengaruhi hasil penelitian. Hasil penelitian menunjukkan lebih dari 50\% pasien COVID-19 yang dirawat inap di RS X berjenis kelamin laki-laki. Hasil ini sesuai dengan penelitian cohort retrospective oleh hu dkk. terhadap 136 pasien terdapat $71,5 \%$ laki-laki. ${ }^{11}$ Beberapa penyebab diduga menyebabkan laki-laki lebih berisiko adalah karena wanita memproduksi lebih banyak interferon 1 (IFN-1) yang merupakan antiviral cytokine yang poten dan penting dalam respon awal COVID-19. ${ }^{12}$ Hasil ini berbeda dengan penelitian Gesmala dkk. yang menunjukkan pasien yang mengalami COVID-19 di Situbondo Indonesia lebih banyak perempuan $(57,6 \%) .{ }^{13}$

Berdasar atas klasifikasi usia, hasil penelitian menunjukkan pasien COVID-19 yang dirawat inap di RS X, paling banyak adalah rentang umur 41-60 tahun (50\%), hasil penelitian ini tidak jauh berbeda dengan penelitian Li dkk. pada 5.913 kasus COVID-19 di Cina menunjukkan bahwa 2.366 pasien COVID-19 berada pada rentang umur 40-59 tahun dengan persentase sebesar $44,49 \% .{ }^{14}$ Usia 40 tahun merupakan usia produktif, dimana pada usia tersebut manusia banyak melakukan interaksi sosial dengan manusia lain dan pada usia tersebut telah mulai terjadi proses aging dan penurunan fungsi fisiologis sistem imun pada populasi yang lebih tua. ${ }^{14}$. Hasil penelitian ini berbeda dengan hasil penelitian M. Gesmalah dkk. yang menunjukkan bahwa mayoritas pasien COVID-19 berada di rentang umur 19-37 tahun dan $38-56$ dengan persentase berturut-turut sebesar $36,8 \%$ dan $32,5 \% .{ }^{13}$ 
Pada penelitian ini hasil pemeriksaan rontgen toraks pasien mayoritas menunjukkan gambaran bronkopneumonia bilateral $(73,09 \%)$. Data ini menunjukkan bahwa lebih dari $3 / 4$ pasien di RS X memiliki gambaran bronkopneumonia dan pneumonia. Hal ini merupakan gambaran radiologis khas pada pasien yang mengalami perburukan paru karena kerusakan epitel bronhus dan alveolus oleh virus. ${ }^{15}$ Penelitian dari Hu dkk. juga menunjukkan bahwa 96,4\% pasien COVID-19 dengan gejala berat mengalami bilateral lung involvement dengan multiple lesions. ${ }^{11}$

Hasil penelitian ini menujukkan komorbid utama pasien COVID-19 yang dirawat adalah hipertensi dengan persentase $60,18 \%$. Kondisi ini merupakan salah satu faktor kunci yang dapat menyebabkan pasien ke arah kritis dibanding dengan pasien yang sehat. Hal ini disebabkan oleh monosit pasien yang mengalami hipertensi akan menghasilkan IL-6 lebih banyak setelah stimulasi angiotensin II atau lipopolisakarida yang menyebabkan disregulasi imun pada penderita hipertensi. Kondisi ini akan memperburuk manifestasi klinis pasien. ${ }^{16}$

Hasil ini sesuai dengan penelitian Zahr dkk. yang mendapati bahwa mayoritas komorbid yang dimiliki pasien adalah hipertensi $(73,8 \%)$, yang diikuti oleh CVD $(42,5 \%)$ dan diabetes $(35,5 \%)$. Komorbid lainnya yang ditemukan adalah penyakit paru obstruktif kronis, obesitas, gagal ginjal dan keganasan. ${ }^{17}$

Lama perawatan pasien COVID-19 di RS X mayoritas adalah 1-7 hari pada pasien hidup dengan persentase 56,4\%, dari 33 pasien COVID-19 yang meninggal terdapat 25 pasien (74,8\%) dirawat selama 1-7 hari dan 8 pasien (24,2\%) dirawat 8-14 hari. Jadi, dapat disimpulkan bahwa pada penelitian ini semua pasien yang meninggal berada dalam durasi lama rawat 1-14 hari. Penelitian macedo dkk. menyimpulkan bahwa lama rawat pasien COVID-19 dipengaruhi oleh usia yang lebih tua, terdapat gejala parah seperti sesak napas, dan komorbiditas seperti gagal ginjal. ${ }^{18}$

Tingkat ekspresi gen relatif dinilai dengan menghitung kuantifikasi relatif dengan membandingkan ekspresi gen SARS-CoV-2 dengan ekspresi gen internal control menggunakan metode Livak $\left(2^{-\Delta \Delta \mathrm{CT}}\right)$. Kontrol yang digunakan dalam perhitungan ini adalah pasien terkonfirmasi COVID-19 yang tidak menunjukkan gejala. Rasio CT dihitung dengan membandingkan antara CT internal control dan CT gen E.

Pada penelitian ini tidak terdapat hubungan antara rasio CT IC/CT gen $E$ dan ekspresi relatif gen ESARS-CoV-2 dengan kejadian gagal napas pada pasien rawat inap COVID-19. Penelitian oleh Chen dkk. juga mendapatkan bahwa tidak ada hubungan antara CT yang rendah (viral load tinggi) terhadap gejala pasien COVID-19. ${ }^{19}$ Hasil yang berbeda didapatkan oleh J.Kaur dkk. bahwa pada pasien yang memiliki gejala olfactory taste disorder (OTD) memiliki angka CT value gen $E, N$, dan $R d R p$ yang rendah yang menunjukkan tingginya viral load pada pasien tersebut tinggi dan memengaruhi terjadinya gejala OTD. ${ }^{3}$

Penelitian lain menunjukkan bahwa nilai CT memiliki hubungan dengan kematian, keparahan penyakit, dan gejala yang muncul pada pasien. ${ }^{20}$ Perbedaan hasil penelitian disebabkan oleh banyak faktor yang dapat memengaruhi tingkat keparahan pasien, seperti usia dan korbiditas yang ada pada pasien. ${ }^{21}$ Faktor lain yang dapat memengaruhi hasil penelitian adalah ketidakakuratan teknik pengambilan sampel, pengumpulan, pengiriman sampel, dan juga keterampilan tenaga kesehatan dalam proses pengambilan sampel sehingga mengganggu homogenitas hasil PCR yang didapat dan akan memengaruhi hasil penelitian. ${ }^{5,7,22,}$

Penelitian ini mempunyai beberapa keterbatasan, antara lain penelitian dilakukan dengan metode cross sectional sehingga tidak dapat dilihat bagaimana ekspresi gen secara langsung memengaruhi kejadian gagal napas. Selain itu data CT diambil dari data sekunder laboratorium, sehingga peneliti tidak dapat memantau kualitas sampel dan prosedur pengerjaan. Data banyak yang kurang lengkap juga menjadi alasan dari banyak data yang dieksklusi. 


\section{Kesimpulan}

Penelitian ini menunjukkan tidak terdapat hubungan antara rasio CT IC/CT gen $E$ dan ekspresi relatif gen E SARS-CoV-2 dengan kejadian gagal napas pada pasien rawat inap COVID-19. Penelitian selanjutnya dapat dilakukan dengan metode kohort dan pengambilan data CT secara mandiri oleh peneliti untuk meningkatkan kualitas kontrol terhadap spesimen dan data.

\section{Acknowledge}

Penelitian ini terselenggara berkat dukungan penuh dari Lembaga Penelitian dan Pengabdian Kepada Masyarakat (LPPM) Universitas Islam Bandung yang mendukung pendanaan penelitian ini (kontrak hibah PDU nomor 100/B.04/LPPM/XII/2020).

\section{Daftar Pustaka}

[1] Kumar Samudrala P, Kumar P, Choudhary K, Thakur N, Suresh Wadekar G, Dayaramani R, dkk. Virology, pathogenesis, diagnosis and in-line treatment of COVID-19 Pavan. 2020;883:173375.

[2] Long C, Xu H, Shen Q, Zhang X, Fan B, Wang C, dkk. Diagnosis of the Coronavirus disease (COVID-19): rRT-PCR or CT? Eur J Radiol. 2020;126(February):108961.

[3] Jain A, Pandey AK, Kaur J, Kumar L, Singh M, Das S, dkk. Is there a correlation between viral load and olfactory \& taste dysfunction in COVID-19 patients? Am J Otolaryngol. 2021;42(3):102911.

[4] Burhan E, Dwi Susanto A, Isbaniah F, Aman Nasution S, Ginanjar E, Wicaksono Pitoyo C, dkk. pedoman tatalaksana COVID-19 Edisi 3.

[5] Lippi G, Simundic AM, Plebani M. Potential preanalytical and analytical vulnerabilities in the laboratory diagnosis of coronavirus disease 2019 (COVID-19). Clin Chem Lab Med. 2020;58(7):1070-6.

[6] Kakhki RK, Kakhki MK, Neshani A. COVID-19 target: a specific target for novel coronavirus detection. Gene Reports. 2020 May ;20:19-21.

[7] Payne D, Newton D, Evans P, Osman H, Baretto R. Preanalytical issues affecting the diagnosis of COVID-19. J Clin Pathol. 2020;1-2.

[8] Dramé M, Tabue Teguo M, Proye E, Hequet F, Hentzien M, Kanagaratnam L, dkk. Should RT-PCR be considered a gold standard in the diagnosis of COVID-19? J Med Virol. 2020;92(11):2312-3.

[9] Tahamtan A, Ardebili A. Real-time RT-PCR in COVID-19 detection: issues affecting the results. Expert Rev Mol Diagn. 2020;20(5):453-4.

[10] Asselah T, Durantel D, Pasmant E, Lau G, Schinazi RF. COVID-19: Discovery, diagnostics and drug development. 2020.

[11] Hu X, Zeng W, Zhang Y, Zhen Z, Zheng Y, Cheng L, dkk. CT imaging features of different clinical types of COVID-19 calculated by AI system: a Chinese multicenter study. J Thorac Dis. 2020 Oct 1 [cited 2021 Oct 6];12(10):5336-46.

[12] Peckham H, de Gruijter NM, Raine C, Radziszewska A, Ciurtin C, Wedderburn LR, dkk. Male sex identified by global COVID-19 meta-analysis as a risk factor for death and ITU admission. Nat Commun. 2020;11(1):1-10.

[13] Gesmalah M, Kesehatan AH-KJ, 2021. Epidemiological Pattern of COVID-19 Infection from March to November 2020 in Situbondo District, East Java, Indonesia. JournalFkmUiAcId. 2021;16(1):23-8.

[14] Li H, Wang S, Zhong F, Bao W, Li Y, Liu L, dkk. age-dependent risks of incidence and mortality of COVID-19 in Hubei Province and other Parts of China. Front Med. 2020 Apr 30;0:190.

[15] Alipoor SD, Jamaati H, Tabarsi P, Mortaz E. Immunopathogenesis of pneumonia in covid19. Tanaffos. 2020;19(2):79-82. 
[16] Wang X, Zhang H, Du H, Ma R, Nan Y, Zhang T. Risk factors for COVID-19 in patients with hypertension. Can J Infect Dis Med Microbiol. 2021;2021.

[17] Ejaz H, Alsrhani A, Zafar A, Javed H, Junaid K, Abdalla AE, dkk. COVID-19 and comorbidities: deleterious impact on infected patients. J Infect Public Health. 2020;13(12):1833-9.

[18] Macedo MCF, Pinheiro IM, Carvalho CJL, Fraga HCJR, Araujo IPC, Montes SS, dkk. Correlation between hospitalized patients' demographics, symptoms, comorbidities, and COVID-19 pandemic in Bahia, Brazil. PLoS One. 2020;15(12 December):1-15.

[19] Chen W, Xiao Q, Fang Z, Lv X, Yao M, Deng M. Correlation Analysis between the viral load and the progression of COVID-19. Comput Math Methods Med. 2021;2021.

[20] Severity D, Sequelae S, Trunfio M, Venuti F, Alladio F, Longo BM, dkk. Diagnostic SARS$\mathrm{CoV}-2$ cycle threshold value predicts disease Severity, Survival, and Six-Month Sequelae in COVID-19 Symptomatic Patients. 2021;

[21] Sanyaolu A, Okorie C, Marinkovic A, Patidar R, Younis K, Desai P, dkk. Comorbidity and its impact on patients with COVID-19. SN Compr Clin Med. 2020;2(8):1069-76.

[22] Manurung JJ, Sukohar A. Hubungan antara CT value pada test RT-PCR terhadap parameter klinis pasien COVID-19 relationship between CT value on RT-PCR test and clinical parameters of COVID-19 patients. Medula. 2021;11:119-24. 